\title{
People's preference on water supply in uncovered Bandung water municipal company area service
}

\author{
Heru Purboyo Hidayat Putro *
}

Department of Regional and City Planning, Institute of Technology Bandung, Bandung, Indonesia

\section{A RT ICLE INFO}

\section{Article history:}

Received 18 July 2016

Received in revised form

3 November 2016

Accepted 19 December 2016

\section{Keywords:}

Municipal water company

Service coverage

Cost-effectiveness analysis

Bandung

\begin{abstract}
A B S T R A C T
One of the problems of water services in urban areas, especially in Bandung, is due to the low coverage of services area. The limitations of the water pipe network services, which is considered as an ideal service by water municipal company, has an impact on alternative uses of other sources such as private wells, communal, rainwater, river water or buying from other sources. The main objective of this study is to assess the water supply system in the uncovered region in Bandung area, which focused on the economic aspects through the analysis of cost effectiveness, service aspects are evaluated based on indicators of overall water services and also preferences towards the services by means of offering water services to the public live in the study area. The survey and analysis results on uncovered areas in Bandung shows that is as much as $81 \%$ using wells system, either deep wells or shallow wells, while the other $17 \%$ are using the communal spring services, and $2 \%$ bought water. This study showed that the existing water services are considered as cost-effectiveness and most people prefer to remain to utilize existing services as long as the performances of the existing services are not having any problem.
\end{abstract}

(C) 2016 The Authors. Published by IASE. This is an open access article under the CC BY-NC-ND license (http://creativecommons.org/licenses/by-nc-nd/4.0/).

\section{Introduction}

Clean water or drinking water is the right or the basic need which must be provided for the sustainability of human life and for supporting daily activities which means that each person has to have access towards clean water. This is implicated also in the field of planning and development of a region/city especially in the aspect of infrastructure which has to be provided to meet the need of clean water for the people in the region/city. Clean water service in urban area is still significantly lacking especially in metropolitan cities, big cities, mediumsized cities, and small towns. According to Prihatin (2013) the clean water problem is caused by three factors, namely population problem, lack of service scope from water municipal company (PDAM) and the effect of seasonal changes. Regarding the service scope from PDAM, according to Indonesia National Board of Drinking Water (BPPSPAM) data in 2011 the national service scope of drinking water was still low at 55.04 percent. The service scope of piping in

\footnotetext{
* Corresponding Author.

Email Address: herupur@pl.itb.ac.id (H. P. H. Putro) https://doi.org/10.21833/ijaas.2016.12.015

2313-626X/C) 2016 The Authors. Published by IASE.

This is an open access article under the CC BY-NC-ND license

(http://creativecommons.org/licenses/by-nc-nd/4.0/)
}

rural areas was 13.94 percent; in urban areas, it was 41.88 percent; and nationally, it was 27.05 percent, while the level of average water leaks nationally was 33 percent.

The city of Bandung as one of the big cities in Indonesia is always related to the problems of clean water and drinking water service. This can be seen from the data from Bandung Water Municipal Company (PDAM Tirtawening) in April 2014 in which the level of service of piping network only reached $69.30 \%$ of the population of Bandung or 2.486.457 people. The limited piping network service considered as an ideal service from PDAM results in the use of alternative sources, such as individual wells, communal sources, rain water, river water, as well as other sources. Adopting a clean water supply system is generally influenced by technical aspects (standard water unit, production unit, distribution unit, service unit, and management unit) as well as non-technical aspects (funding/finance, social, and institution).

Based on the aspects and factors influencing clean water supply, the challenge to be studied then was how clean water supply in areas which had not been covered by PDAM service identified based on aspects or factors affecting the provision of clean water service. This research was aimed at studying clean water supply system from various supply 
alternatives found in areas which had not been provided with piping network (PDAM) with the consideration of users' preferences on PDAM service.

According to Whitfield (2006), a water supply system which is able to provide water which can be consumed in sufficient amount is crucial for a big, modern city. A modern water supply system comprises of supply sources, reservoir facilities, distribution facilities (to processing), processing facilities, processing facilities, distribution facilities (from processing) temporary reservoir, and distribution facilities.

Indonesian Republic Governmental Regulation No Year 2005 on Improvement of Drinking Water Supply System explained that the provision of clean water covers technical aspects (raw water unit, production unit, distribution unit, service unit, and management unit) and non-technical aspects (covers funding/finance, social, and institution) Marella (1992) explained that many factors affect the provision of clean water supply for the community. Five main categories affecting clean water service, among others 1) Population, 2) Climate 3) Socioeconomic condition, 4) cost of clean water, 5) water conservation and water resource alternatives. Factors which give influence on drinking water supply system options according to Henriques (2009) are: 1) Institutional: regulation (rules), administration , process; 2) Human Resources (HR): the availability of skilled workers; 3) Technical: availability of spare parts; 4) Economy/Finance: funding variation, funding mechanism, capital cost, operational and maintenance; 5) Environment: rainfall, soil type, water resource type; 6) Energy: access to energy source, energy use cost; 7) Social: women's participation, organization within the community; 8) Level of Service : service improvement, water supply.

Based on aspects and factors influencing the supply of clean water, thus the focus of research was specifically aimed at economic aspect especially cost effectiveness, level of clean water service, and equipped with users' preference if improvement is increased towards the existing service system. Clean water economic aspect becomes one of the important aspects in clean water service provision. Economic aspect covers funding and tariff to be one of the factors considered by households to gain as well as increase clean water service. Funding in this research is cost of supply, operational, and maintenance as variables in identifying cost of clean water service provision effectiveness. Level of clean water service especially related to factors of quality, quantity and continuity has significant influence towards people's willingness in using existing clean water service system as well as improving it with better supply system. Improvement of clean water service as a whole is observed from preference aspect of users to improvement of clean water service and ability and willingness in paying improvement in the service system.

\section{Methods}

Approach in the study of clean water supply in areas which had not been provided with piping network from PDAM used descriptive quantitative and qualitative approaches since the process of analysis in this research used numerical data and the people's perceptions on clean water service. According to Nazir (2005) descriptive analysis method is a research method on the status of a group of people, an object and a set of conditions, a system of idea or an event at present. Descriptive research on clean water supply is by describing the value of effectiveness of supply system as well as capability and willingness of the community on the improvement of clean water supply system.

Data analysis used in this research was conducted using descriptive quantitative by firstly grouping and processing data so that the analysis process was made easier. Identification towards the types of clean water service in areas which had not been provided with PDAM service by conducting survey on the community with the total samples of 300 respondents. Distribution of questionnaires was conducted at study area determined based on scope of PDAM service, i.e. in Subdistricts (Kecamatan) Ujung Berung and Cibiru in Eastern part of Bandung and Bandung Kulon in Wastern part of Bandung.

Analysis on budget especially related to effectiveness of cost of clean water service provision was conducted using Cost Effectiveness Analysis. Cost Effectiveness Analysis (CEA) is an analysis to determine the best alternatives in activity, process as well as intervention which can minimize resources to reach the intended results (Wholey et al., 2010). Preference on service from PDAM was equipped with Ability to Pay and Willingness to Pay analyses of the community towards service from PDAM. Results from analysis was aimed to find out clean water service in areas which had not been provided with service from PDAM so that it will be useful as basic consideration from the government as well as related stakeholder to create policy in the effective provision of clean water from various alternatives of clean water supply.

\section{Results and discussion}

In general, housing areas in the area of study are dwelling areas with people of middle-class level of income, permanently built houses and relatively densely populated in some areas but not densely populated in other areas. The buildings are wellplanned according to street plan and developed as villages, also relatively satisfactory in the aspect of hygiene and equipped with garbage dumps at several locations.

\subsection{Clean water service}

Water resources used based on survey result of respondents in areas were $83 \%$ from ground water (private wells), while $17 \%$ were using communal spring water. The communal ground water mentioned was ground water from mountain spring 
water which was then managed by the local people or private companies distributed to the community at certain rate of tariffs.

Results of survey of respondents on water consumption showed that the need for clean water on total average per day was \pm 338 liter per family/day. The quantity of the highest clean water use was $1500 \mathrm{l} /$ family/day, while the lowest was 20 l/family/day. The clean water consumption, on average is 74 liter/day/capita. If this is compared to the need for clean water per person based on Indonesia National Standard (SNI 19-6728.1-2002) for urban community, clean water needed is 120 l/day/capita. Therefore, it can be concluded that the rate of clean water usage in the location of study was below standard.

Water quality is related to risks of diseases which may be caused by consuming water from a certain resource. Based on the Regulation from the Health Minister, the quality of clean water may be identified from the color, odor and taste (Table 1).

Table 1: Clean water quality

\begin{tabular}{|c|c|}
\hline Water Quality & Total \\
\hline Colored & 27 \\
\hline No Color & 273 \\
\hline With Taste & 6 \\
\hline With No Taste & 294 \\
\hline With Odor & 21 \\
\hline With No Odor & 279 \\
\hline
\end{tabular}

In the aspect of quality which has an implication on risks towards health, clean water service in area of study was still not optimal. Based on survey result on water quality, it was found that $9 \%$ was colored, $2 \%$ had taste and $7 \%$ had odor.

Quantity of water related to the total water to be provided to fulfill daily need. According to WHO standard, the minimum need of clean water is 20 $\mathrm{l} /$ person/day and the optimal is $100 \mathrm{l} /$ person/day. The average clean water consumption in study location was 74 liter/day/capita which indicated that the water quantity in general was still not optimal.

Table 3: Cost effectiveness ratio (CER) of clean water service Clean Water Service Alternative Cost Effectiveness Ratio

\begin{tabular}{|c|c|}
\hline Public Hydrant & 0.572 \\
\hline Water Terminal & 0.953 \\
\hline Shallow Well & 1.026 \\
\hline Communal Spring Water & 1.090 \\
\hline PDAM & 1.157 \\
\hline Deep Well & 1.231 \\
\hline Water Tank Truck & -0.351 \\
\hline
\end{tabular}

In CEA analysis, CER value which was decreasing showed cost spent to obtain certain output to be more effective and negative value showed the increase in cost or decrease in efficiency implementation of the scenario or the service planned. Based on calculation of cost effectiveness ratio (CER), it was found that the rate with the lowest CER was public hydrant service which was 0,572 and next it was water terminal service which was 0,953 .
Continuity refers to stability of service in certain period while reliability is the ability of supply system from disturbances or detriments that might take place (Table 2).

Table 2: Clean water service continuity

\begin{tabular}{|c|c|}
\hline Availability (Continuity) & Total \\
\hline Always Available & 255 \\
\hline Not Always Available & 45 \\
\hline
\end{tabular}

In the aspect of clean water service continuity in area of study was still not optimal in which $15 \%$ respondents experienced clean water shortage at certain times or seasons.

\subsection{Clean water funding aspect (Economy)}

The cost of water service for households is influenced by availability of water resource, cost construction from water system, operational and maintenance costs, capital maintenance cost, expense for direct and indirect support (Kayser et al., 2013). Survey result towards cost of community clean water resource provision which mainly were private wells, was that average cost spent was Rp 3.427.767 for shallow well and Rp 4.451.556 for deep well. Maximum cost spent for clean water supply was Rp 10.000.000 which was for deep well provision.

Cost of maintenance clean water supply system on average was Rp.138.667 up to Rp 330.357 per year with maintenance activity in general in the form of repair as well as replacing part of pumps and cleaning. In the system of communal clean water supply using spring water in the area of study was conducted using pipes with funding from each household. Tariff charged for clean water service from communal spring water in area of study was \pm Rp.20.000 - Rp 30.000 per month.

Through Cost Effectiveness analysis, the most effective service identified in the aspect of funding as explained in the following (Table 3).

\subsection{Preference towards water municipal company (PDAM) service}

Based on willingness or intention of the community in using PDAM if provided with better quantity, quality and continuity in their area, it was found that $57 \%$ responded that they were reluctant to change or felt satisfied with the existing water resource; as many as $42 \%$ were willing to turn to using PDAM. 
The average income of the people in the study area was Rp. 2.355.528 and the average expense for clean water was $2.20 \%$ from the income and still below $4 \%$ (four percent) in accordance to the decree of the Indonesia Minister of Internal Affairs Number 23 Year 2006.

To know better about the potentiality of residents to pay water service provided by water municipal company, some of the questions are posed to them, especially on ability and willingness to pay. And its results are as follows. The proportion of people's capability to pay for clean water service at the maximum was Rp.60.000, and which was 88\% which was the highest percentage of the respondents related to the ability to pay for clean water service.

Willingness to pay for the use of clean water in location of study was dominated by willingness to pay of $\leq$ Rp. 30.000 (per /month) towards clean water service of $53 \%$ of the total respondents.

A graph of relation between people's ability and willingness for clean water service is shown in Fig. 1.

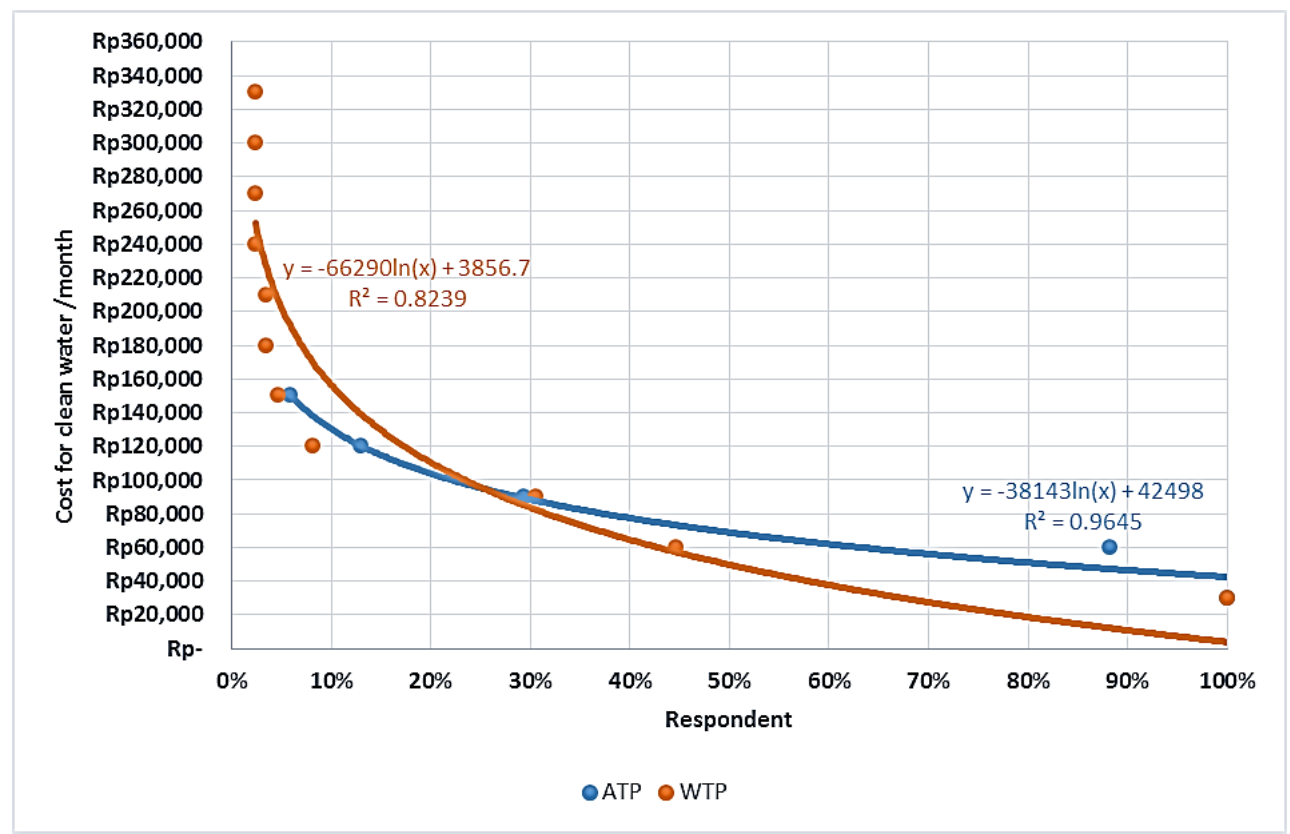

Fig. 1: Trend line of relation of ATP and WTP clean water service

Relation between willingness to pay and ability to pay piped clean water service (PDAM) in area of study showed that almost $70 \%$ of respondents had the ability to pay above willingness to pay which indicated that users had relatively high ability to pay clean water but utility to the service was relatively low, in which the users in this condition was called choiced users.

\section{Conclusion}

This research was aimed at studying clean water supply system from various supply alternatives found in areas which had not been provided service of piping network (PDAM) with the consideration of users' preference towards PDAM service. Based on result of analysis, it can be concluded, clean water supply in areas which had not been provided with piping network (PDAM) was mostly done individually (on site) or by utilizing communal water resources to fulfill household daily needs. As many as $81 \%$ of the people used well supply system either shallow well or deep well while the other $17 \%$ used services from communal spring water. The survey result which showed that the majority of respondents felt satisfied with the existing services, even the service they get was still not optimal especially in the aspect of continuity, colored, and odor.
The people in the study area have a good economic ability to join and pay piped water service, if the Bandung water municipal company expands the service to their area. So it is a challenge for public sector in Bandung municipality to provide service better than what the ordinary resident can make for themselves.

\section{References}

Henriques J (2009). Selecting essential infrastructure for sustainable metabolisms in developing communities. In Graduate Research Conference: Sustainable Cities for the Future, Universities of Melbourne and Queensland, Brisbane, Australia.

Kayser GL, Moriarty P, Fonseca C, and Bartram J (2013). Domestic water service delivery indicators and frameworks for monitoring, evaluation, policy and planning: a review. International Journal of Environmental Research and Public Health, 10(10): 4812-4835.

Marella RL (1992). Factors that affect public-supply water use in Florida, with a section on projected water use to the year 2020. U.S. Geological Survey, Reston, USA. 
Nazir M (2005). Metode Penelitian. [Research Methods]. Ghalia Indonesia. Bogor. [In Indonesian].

Prihatin RB (2013). Problem Air Bersih di Perkotaan [Problems of urban water]. Jurnal Info Singkat, 5(7): 9-12. [In Indonesian].
Whitfield L (2006). The politics of urban water reform in Ghana. Review of African Political Economy, 33 (109): 425-448.

Wholey JS, Hatry HP, and Newcomer KE (2010). Handbook of Practical Program Evaluation. $3^{\text {rd }}$ Edition, Jossey-Bass, San Francisco, USA. 